\title{
Transplantation of Mouse Embryonic Stem Cells into the Cochlea of an Auditory-Neuropathy Animal Model: Effects of Timing after Injury
}

\author{
Hainan Lang ${ }^{1}$, Bradley A. Schulte ${ }^{1,2}$, John C. Goddard ${ }^{2}$, Michelle Hedrick ${ }^{1}$, \\ Jason B. Schulte ${ }^{1}$, Ling Wei ${ }^{1}$, ANd Richard A. Schmiedt ${ }^{2}$ \\ ${ }^{1}$ Department of Pathology and Laboratory Medicine, Medical University of South Carolina, 165 Ashley Avenue, P.O. Box \\ 250908, Charleston, SC 29425, USA \\ ${ }^{2}$ Department of Otolaryngology-Head E Neck Surgery, Medical University of South Carolina, Charleston, SC 29425, USA
}

Received: 26 May 2007; Accepted: 6 March 2008; Online publication: 1 May 2008

\begin{abstract}
Application of ouabain to the round window membrane of the gerbil selectively induces the death of most spiral ganglion neurons and thus provides an excellent model for investigating the survival and differentiation of embryonic stem cells (ESCs) introduced into the inner ear. In this study, mouse ESCs were pretreated with a neural-induction protocol and transplanted into Rosenthal's canal (RC), perilymph, or endolymph of Mongolian gerbils either 1-3 days (early post-injury transplant group) or 7 days or longer (late post-injury transplant group) after ouabain injury. Overall, ESC survival in RC and perilymphatic spaces was significantly greater in the early post-injury microenvironment as compared to the later post-injury condition. Viable clusters of ESCs within RC and perilymphatic spaces appeared to be associated with neovascularization in the early post-injury group. A small number of ESCs transplanted within RC stained for mature neuronal or glial cell markers. ESCs introduced into perilymph survived in several locations, but most differentiated into glia-like cells. ESCs transplanted into endolymph survived poorly if at all. These experiments demonstrate that there is an optimal time window for engraftment and survival of ESCs that occurs in the early post-injury period.
\end{abstract}

Correspondence to: Hainan Lang ${ }^{1}$. Department of Pathology and Laboratory Medicine - Medical University of South Carolina - 165 Ashley Avenue, P.O. Box 250908, Charleston, SC 29425, USA. Telephone: +1-843-7922711; fax: +1-843-7920368; email: langh@, musc.edu
Keywords: embryonic stem cells, spiral ganglion neurons, hearing loss, inner ear, Rosenthal's canal, injured microenvironment, neovascularization

\section{INTRODUCTION}

The application of stem/progenitor cell transplantation for replacement and regeneration of degenerated neural tissue in the inner ear offers a potential strategy for reversing sensorineural hearing loss (SNHL; see reviews of Dazert et al. 2003; Bianchi and Raz 2004; Li et al. 2004; Watters et al. 2004; Nakagawa and Ito 2004; Parker and Cotanche 2004; Matsui et al. 2005; Pellicer et al. 2005; Hu and Ulfendahl 2006; Coleman et al. 2007). Although attempts to introduce neural tissue or stem cells directly into the inner ear of various animal models with auditory nerve degeneration have met with varying degrees of success, it appears that injury before transplant increases the survival rate of the transplanted cells. For example, Hu et al. (2005) delivered adult neural stem cells into the scala tympani of normal and deafened guinea pigs and found that the survival rate of transplanted cells was better in animals treated with neomycin 2 days before transplantation than in normal untreated animals. Okano et al. (2005) reported that the average number of surviving transplanted cells within the modiolus of injured ears was about double that seen in normal ears. It has also been shown that embryonic stem cells (ESCs) are able to survive, and migrate along the entire course of an injured auditory nerve, and form 
nerve projections into the organ of Corti (Sekiya et al. 2006; Corrales et al. 2006). It is highly likely that injury-induced microenvironmental changes contribute to the engraftment and differentiation capacity of cells transplanted into the inner ear under specific conditions of injury. Further understanding of the host environmental changes that regulate the survival and differentiation of transplanted cells is crucial in the development of effective and safe cell replacement treatment for SNHL. The ouabain-induced auditory neuropathy model has been shown to selectively destroy most spiral ganglion neurons (SGNs) with little effect on the morphology and function of the sensory hair cells and cells in the cochlear lateral wall (Schmiedt et al. 2002; Lang et al. 2005; Corrales et al. 2006). Thus, this model is ideal for investigating the fate of stem/progenitor cells in the inner ear as well as the effects of the host microenvironment on survival and differentiation of the transplanted cells.

Potential cell sources for inner ear transplantation include fetal dorsal root ganglion cells (Hu et al. 2004; Regala et al. 2005), neural progenitor cells (Ito et al. 2001; Corrales et al. 2006;), stem or progenitor cells isolated from inner ear ( $\mathrm{Li}$ et al. 2003a; Doetzlhofer et al. 2004; Rask-Andersen et al. 2005; Zhai et al. 2005), immortalized auditory neuroblast cells (Nicholl et al. 2005; Liu et al. 2006a, b), ESCs and their derived neuronal cells ( $\mathrm{Li}$ et al. 2003b; $\mathrm{Hu}$ et al. 2004, 2005; Hildebrand et al. 2006; Okano et al. 2005; Regala et al. 2005; Coleman et al. 2006; Sakamoto et al. 2004; Sekiya et al. 2006; Corrales et al. 2006), and marrow stromal cells treated with sonic hedgehog and retinoic acid (Kondo et al. 2005). ESCs derived from the inner cell mass of the blastocyst are capable of undergoing an unlimited number of divisions and differentiating into cell types of all three germ layers. The introduction of undifferentiated ESCs into host tissue is problematic, as these cells have a propensity to form teratomas in unregulated microenvironments (Chung et al. 2006). Several methods exist to direct the differentiation of ESCs to neural lineages in vitro (Bain et al. 1995; Bain and Gottlieb 1998; Okabe et al. 1996) and avoid this problem. For this study, we chose to use the retinoic acid (RA) neural induction protocol (Bain et al. 1995; Bain and Gottlieb 1998) because this procedure can induce ESCs to generate neuron- and glia-like cells when transplanted into host neural tissues in both central and peripheral nervous systems (McDonald et al. 1999; Meyer et al. 2005; Wei et al. 2005).

The SGNs reside in Rosenthal's canal (RC), a bony channel within the core of the cochlea. Although the precise delivery of cells into the specific regions of the inner ear is challenging, our laboratory has developed a postauricular approach that allows the delivery of cells into several sites within the gerbil inner ear. In the present study, mouse ESCs treated with the RA neural induction protocol were transplanted directly into RC, perilymph, or endolymph after short or long recovery periods following exposure to ouabain.

\section{MATERIALS AND METHODS}

Animal and surgical procedures

Mongolian gerbils of both genders aged 3-6 months with healthy external ears were used for this study. The animals were born and raised in low-noise environment [median sound level was $40 \mathrm{~dB}$ sound pressure level (SPL)] at the Animal Research Facility of the Medical University of South Carolina. All aspects of the animal research were conducted in accordance with the guidelines of the local Institutional Animal Care and Use Committee.

Animals were anesthetized with pentobarbital sodium (50 mg/kg) and given atropine $(0.2 \mathrm{mg} / \mathrm{kg})$ to reduce respiratory secretions. Body temperature was maintained between $37^{\circ} \mathrm{C}$ and $38^{\circ} \mathrm{C}$ using a heating pad. Sterile procedures were used to open the bulla and place about 20-40 $\mu \mathrm{l}$ of a $1 \mathrm{mM}$ ouabain (Sigma, O-3125) solution in normal saline in the RW niche. After $30 \mathrm{~min}$, the ouabain solution was removed by wicking with a small piece of filter paper. The surface of the bulla was fully closed with dental cement, and the incisions were closed with sutures. Postsurgical discomfort was treated with buprenorphine if necessary. The animals allowed to recover for 1-3 days after ouabain exposure before transplantation were designated as the early post-injury (EPI) transplant group, whereas animals allowed to recover for 7 days or longer were designated as the late post-injury (LPI) transplant group.

\section{ESC transplantation}

Procedures for animal preparation and anesthesia were similar to those described above. The bulla was surgically exposed and opened to permit access to the cochlea using a postauricular incision. The RW niche was opened widely by removing a few pieces of thin bone from the bony wall. This preparation allows direct visualization of the bony osseous spiral lamina, part of the central modiolus and the bony wall of RC in the hook and lower basal turn where most basal spiral ganglion neurons are located (Fig. 1A). The three approaches for transplanting ESCs into ouabainexposed ears included direct RC injection, perilymphatic injection, and endolymphatic injection (Fig. 1B). Glass micropipettes (WPI, Sarasota, FL) were pulled and the tips broken to a diameter of 20-30 $\mu \mathrm{m}$. A Nanoliter Microinjection System (WPI) and micromanipulator were used to deliver controlled amounts of cells in suspension. To avoid the formation of cell clusters, the ESCs were treated by gently pipetting up 

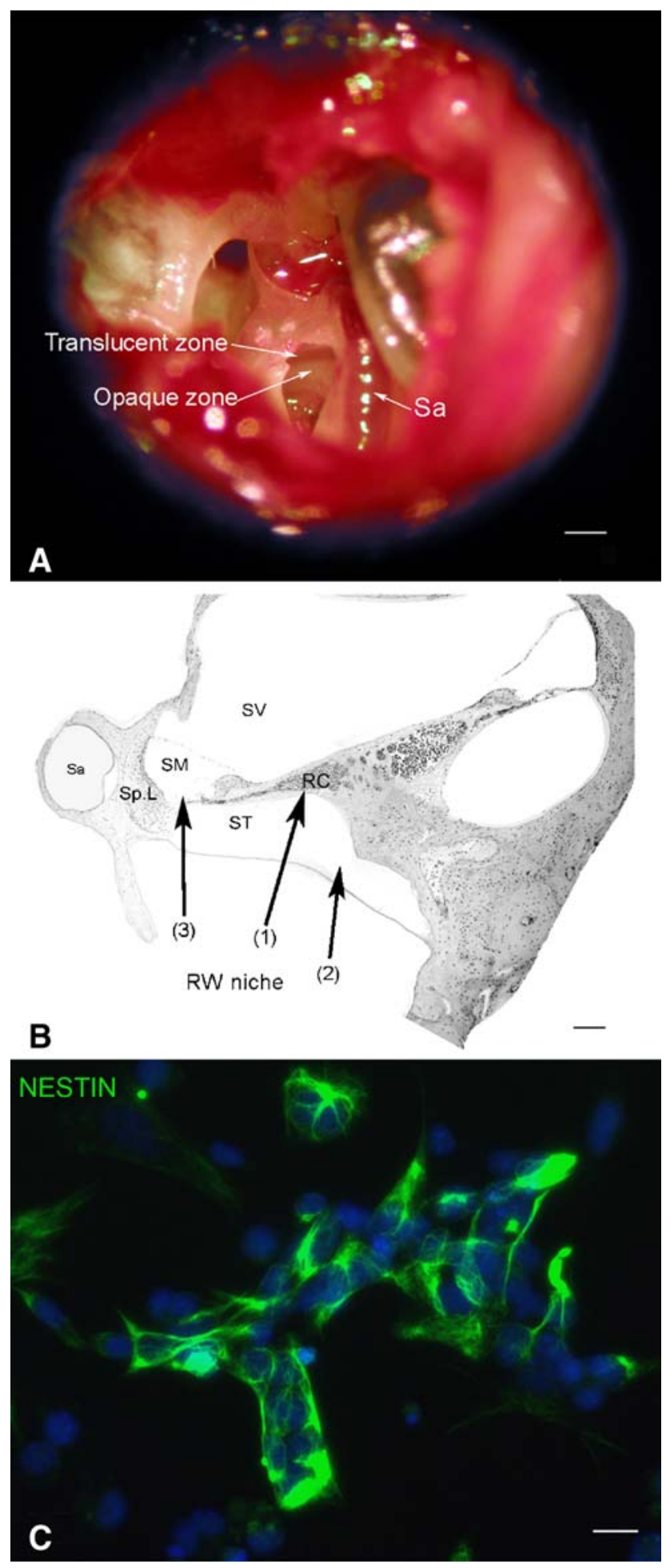

and down approximately ten times with a 0.2-ml pipette tip before loading them into a glass micropipette. The injected volume per site was about $3 \mu \mathrm{l}$ with a cell density of $3-4 \times 10^{6}$ cells $/ \mathrm{ml}$. For perilymphatic injection, ESCs were directly delivered into the scala tympani by breaking through the RW membrane (Fig. 1B). For endolyphmphatic injection, the micropipette tip was positioned toward the basilar membrane (the translu-
4FIG. 1. Approaches used for ESC transplantation and the state of differentiation of ESCs after RA neural induction. A Surgical approach to expose the round window $(R W)$ niche of the gerbil cochlea for ESC transplantation. The basilar membrane comprises the translucent zone and is visible through the RW membrane. The bony osseous spiral lamina, the wall of Rosenthal's canal $(R C)$, and the central modiolus are located in the opaque zone. Scale bar $=500 \mu \mathrm{m}$. B Schematic diagram illustrating three delivery routes of ESCs into: (1) Rosenthal's canal, (2) perilymph of scala tympani (ST), (3) and endolymph of scala media (SM). The photograph was modified from a radial paraffin section of the basal turn from a normal young gerbil. Sa stapedial arteria, Sp.L spiral ligament, SV scala vestibuli. Scale bar $=100 \mu \mathrm{m}$. C The majority of the cultured ESCs stained for nestin (green). Nuclei were countstained with bis-benzimide (b/ue). Scale bar $=20 \mu \mathrm{m}$.

cent zone showing in Fig. 1A). Then, the cells were delivered into the scala media after gently penetrating the RW membrane and the basilar membrane (Fig. 1B). For RC injection, the micropipette tip was carefully pointed toward the bony wall of RC that is located in the central part of the opaque zone shown in Figure 1A. The micropipette tip was then inserted through the $\mathrm{RM}$ membrane, penetrating the thin bony wall of RC and entering into the RC cavity (Fig. 1B). The tip of the pipette was left in place for a minimum of $5 \mathrm{~min}$ after injection to minimize the number of cells leaking from the injection site in RC back into the perilymph. Still, transplanted cells were always identified in the perilymphatic space as a result of cells leaking from the pipette tip and the penetrated site (Table 1).

To suppress rejection of mouse ESCs, gerbils were given daily injection of cyclosporine A $\left(15 \mathrm{mg} \mathrm{kg}^{-1}\right.$ day $^{-1}$ s.c., Sandoz Pharmaceutical Corp., NJ) starting 1 day before surgery and terminating the day before sacrifice. The same dose was given to all animals in this study.

\section{Cell cultures}

Mouse ESCs were prepared for transplantation from (1) wild-type D3 cells, (2) D3 cells engineered to express enhanced green fluorescent protein (EGFP), or (3) D3 cells modified to over-express bcl2 (D.I. Gottlieb, Washington University, St. Louis, MO). The D3 cell line was isolated from day 4 129/Sv blastocysts (Doetschman et al. 1985). The details for EGFP expression and bcl2 gene modification have been described previously (Adams et al. 2003; Wei et al. 2005). The ESC lines were maintained at low passage $(<20)$ with normal karyotype. Cells were passaged, and neural differentiation was induced using the 4-/4+ RA induction protocol (Bain et al. 1995; Bain and Gottlieb 1998). Briefly, undifferentiated cells were maintained in T25 flasks in ES cell growth media (ESGM) consisting of Dulbecco's modified Eagle media (with L-glutamine, without pyruvate, Gibco 11965-043) supplemented with $10 \%$ fetal bovine serum, $10 \%$ new born calf serum, $8.5 \mu \mathrm{g} / \mathrm{ml}$ guanosine, $8 \mu \mathrm{g} / \mathrm{ml}$ adenosine, $7.3 \mu \mathrm{g} / \mathrm{ml}$ 
TABLE 1

Surviving ESCs 3-4 weeks after transplant

\begin{tabular}{|c|c|c|c|c|}
\hline Model & Animal ID & Injection site(s) & Cell type injected & $\begin{array}{l}\text { Mean number of surviving } \\
\text { ESCs per section }(n=5)\end{array}$ \\
\hline EPI & RS472 & RC, PLS & D3/bcl2 & 13 \\
\hline EPI & $\mathrm{RS} 473^{\mathrm{a}}$ & RC, PLS & $\mathrm{D} 3 / \mathrm{bcl} 2$ & $196^{\mathrm{b}}$ \\
\hline EPI & $\mathrm{RS} 477^{\mathrm{a}}$ & RC, PLS & $\mathrm{D} 3 / \mathrm{bcl} 2$ & $90^{\mathrm{b}}$ \\
\hline EPI & RS480 & RC, PLS & D3/EGFP & $199^{b}$ \\
\hline $\mathrm{EPI}$ & $\mathrm{RS} 481^{\mathrm{a}}$ & RC, PLS & D3/EGFP & $74^{\mathrm{b}}$ \\
\hline $\mathrm{EPI}$ & $\mathrm{RS} 482^{\mathrm{a}}$ & RC, PLS & D3 & 15 \\
\hline EPI & $\mathrm{RS} 485^{\mathrm{a}}$ & RC, PLS & $\mathrm{D} 3 / \mathrm{bcl} 2$ & $213^{b}$ \\
\hline EPI & $\mathrm{RS} 486^{\mathrm{a}}$ & RC, PLS & D3/EGFP & 40 \\
\hline EPI & RS487 & RC, PLS & D3/EGFP & 26 \\
\hline $\mathrm{EPI}$ & RS488 ${ }^{a}$ & RC, PLS & D3 & 47 \\
\hline $\mathrm{EPI}$ & RS494 & RC, PLS & $\mathrm{D} 3 / \mathrm{bcl} 2$ & 30 \\
\hline EPI & RS501 & RC, PLS & D3 & 65 \\
\hline $\mathrm{EPI}$ & RS440 & PLS & D3/EGFP & 0 \\
\hline EPI & RS468 & PLS & D3/EGFP & 12 \\
\hline $\mathrm{EPI}$ & $\mathrm{RS} 474^{\mathrm{a}}$ & PLS & $\mathrm{D} 3 / \mathrm{bcl} 2$ & 11 \\
\hline EPI & $\mathrm{RS} 476^{\mathrm{a}}$ & PLS & $\mathrm{D} 3 / \mathrm{bcl} 2$ & $63^{b}$ \\
\hline EPI & $\mathrm{RS} 478^{\mathrm{a}}$ & PLS & $\mathrm{D} 3 / \mathrm{bcl} 2$ & 86 \\
\hline $\mathrm{EPI}$ & RS479 & PLS & $\mathrm{D} 3 / \mathrm{bcl} 2$ & 10 \\
\hline $\mathrm{EPI}$ & RS484 & PLS & $\mathrm{D} 3 / \mathrm{bcl} 2$ & 23 \\
\hline EPI & RS490 & PLS & D3 & 0 \\
\hline EPI & RS491 & PLS & D3 & 0 \\
\hline $\mathrm{EPI}$ & RS495 & PLS & $\mathrm{D} 3 / \mathrm{bcl} 2$ & 56 \\
\hline $\mathrm{EPI}$ & RS499 & PLS & D3 & 63 \\
\hline LPI & RS454 & RC, PLS & D3/bcl2 & 7 \\
\hline LPI & RS456 & RC, PLS & D3/bcl2 & 3 \\
\hline LPI & RS457 & RC, PLS & $\mathrm{D} 3 / \mathrm{bcl} 2$ & 3 \\
\hline LPI & RS469 & RC, PLS & D3/EGFP & 6 \\
\hline LPI & $\mathrm{RS} 471^{\mathrm{a}}$ & RC, PLS & D3/bcl2 & 53 \\
\hline LPI & RS483 & RC, PLS & D3/EGFP & 0 \\
\hline LPI & RS493 & RC, PLS & D3/bcl2 & 0 \\
\hline LPI & RS437 & PLS & D3 & 11 \\
\hline LPI & $\mathrm{RS} 441^{\mathrm{a}}$ & PLS & D3 & 3 \\
\hline LPI & RS442 & PLS & D3 & 0 \\
\hline LPI & $\mathrm{RS} 455^{\mathrm{a}}$ & PLS & D3/bcl2 & 37 \\
\hline LPI & RS458 & PLS & D3/bcl2 & 1 \\
\hline LPI & RS465 & PLS & D3/EGFP & 0 \\
\hline LPI & RS470 & PLS & D3/bcl2 & 0 \\
\hline LPI & RS492 & PLS & $\mathrm{D} 3 / \mathrm{bcl} 2$ & 9 \\
\hline Normal & RS489 & PLS & D3 & 6 \\
\hline Normal & RS496 & PLS & $\mathrm{D} 3 / \mathrm{bcl} 2$ & 0 \\
\hline Normal & RS497 & PLS & $\mathrm{D} 3 / \mathrm{bcl} 2$ & 0 \\
\hline
\end{tabular}

Early post-injury (EPI) and late post-injury (LPI) gerbils received ESCs within 1-3 days and 1-4 weeks after ouabain treatment, respectively $E L S$ endolymphatic space, PLS perilymphatic space, $R C$, Rosenthal's canal

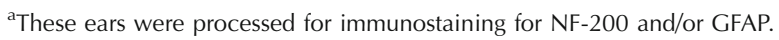

${ }^{\mathrm{b}}$ The vascular remodeling was present in surviving ESC masses.

cytidine, $7.3 \mu \mathrm{g} / \mathrm{ml}$ uridine, $2.4 \mu \mathrm{g} / \mathrm{ml}$ thymidine, $1,000 \mathrm{U} / \mathrm{ml}$ of leukemia inhibitory factor (LIF, Gibco 13275-011), and $10^{-4} \mathrm{M} \beta$-mercaptoethanol.

For neural lineage induction, cells were harvested from the growth flasks by trypsinization with $0.25 \%$ trypsin and ethylenediaminetetraacetic acid (EDTA) in Hanks's salt solution (Gibco, 15050) for $10 \mathrm{~min}$. One quarter of the cells from a T25 flask were seeded into a standard 100-mm bacterial Petri dish in ESC induction medium (ESIM). The ESIM is similar to ESGM, but without LIF and $\beta$-mercaptoethanol. After 2 days, the cell aggregates and the media were removed from the dish, and cells were allowed to settle for $10 \mathrm{~min}$ in a $15-\mathrm{ml}$ centrifuge tube. The medium was then aspirated and replaced with fresh ESIM. Cells were then returned to the culture dish for an additional 2 days. The culture medium was replaced with ESIM containing $5 \times 10^{-7} \mathrm{M}$ RA (all-trans RA, Sigma R-2625), and cells were cultured for an additional 4 days before harvesting for transplant. The state of ESC differentiation after RA $4-/ 4+$ neural induction was in agreement with the results of previous studies (Meyer et al. 2005; Wei et al. 
2005). Although there was heterogeneity among the cell types generated by this protocol, a great majority $(76.2 \pm 3.5 \%)$ of the cultured ESCs were positive for neuronal precursor and/or immature neuron markers such as nestin (Fig. 1C).

\section{Physiological procedures}

The methods for recording the compound action potential (CAP) response, distortion product otoacoustic emissions (DPOAEs), and endocochlear potential (EP) were similar to those previously described (Lang et al. 2005, 2006). Physiological data were obtained from ESC-implanted ears and a group of untreated ears. The animals were anesthetized as described above and fitted to a head holder in a sound- and vibration-isolated booth. The pinna and surrounding tissue were removed and bulla opened widely. The CAP electrode was placed on the bony rim of the RW niche and an acoustic assembly, including a probe-tube microphone (B\&K 4134, Bruel and Kjaer, Norcross, GA) and driver (Beyer DT-48, Beyerdynamic, Farmingdale, NY), was sealed to the bony ear canal with closed-cell foam. Tone pips were calculated in the frequency domain using Tucker Davis Technologies (Alachua, FL) equipment and software. CAP thresholds were obtained visually with an oscilloscope online at half-octave frequencies from 0.5 to $20 \mathrm{kHz}$ with tone pips of 1.8-ms total duration with $\cos ^{2}$ rise/fall times of $0.55 \mathrm{~ms}$. DPOAEs were measured with an Ariel board (Ariel, Canbury, NJ) and CUBeDISP software (Etymotic Research, ELK grove Village, IL). DPOAEs were obtained with an opened bulla after removing the pinna and underlying tissue. The intensity levels of both primaries were fixed at $50 \mathrm{~dB}$ SPL. Primary tones were swept from $f_{2}=4$ to $20 \mathrm{kHz}$ with $f_{1} / f_{2}$ ratio of 1.2 and a resolution of 10 points per octave.

EPs were measured with a micropipette filled with $0.2 \mathrm{M} \mathrm{KCl}$ yielding an impedance of approximately 20-30 M $\Omega$. The output of the micropipette was tied to an electrometer (World Precision Instruments FD 223) for direct recording of the potential. EP was defined as the voltage difference between scala media and a pool of isotonic saline on the neck muscles. The micropipette was introduced into the scala media via 30 - to $50-\mu \mathrm{m}$ holes drilled through the otic capsule of the three cochlear turns. We first measured the EP in the apical turn (T3), followed by the middle turn (T2) and basal turn (T1). This procedure minimizes the trauma of inserting the micropipette into one turn and causing a reduction of the EP in other turns (Schmiedt et al. 2002; Lang et al. 2002).

\section{Tissue preparation and immunocytochemistry}

The inner ears were fixed for $6-8 \mathrm{~h}$ with $4 \%$ paraformaldehyde and then decalcified with EDTA. Tissues were embedded in PARAPLAST ${ }^{\circledR}$ for paraffin sectioning. Deparaffinized and rehydrated sections were immersed in blocking solution for $20 \mathrm{~min}$ and then incubated overnight at $4^{\circ} \mathrm{C}$ with a primary antibody

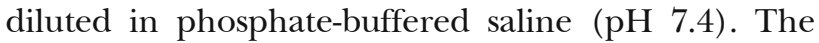
primary antibodies used in this study were rabbit antiGFP (1:200, A11122) or mouse anti-GFP (1:100, A11120) (Molecular Probes, Eugene, OR), rat monoclonal antibody to mouse-specific brain membrane (1:50, M2, Developmental Studies Hybridoma Bank, Iowa City, IA), rabbit anti-bcl2 (1:200, sc492) (Santa Cruz, Santa Cruz, CA), anti-mouse CD45R (1:200, sc19597; Santa Cruz), mouse anti-neurofilament 200 (1:200, Clone N52, N0142; Sigma, Atlanta, GA) and mouse anti-glial fibrillary acidic protein (GFAP; 1:200, MAB360; Chemicon, Temecula, CA). An antigen retrieval treatment was used for immunostaining with mouse brain membrane-specific antibody M2.

The antibodies employed in this study have been widely used and are well characterized. The rabbit anti-GFP polyclonal antiserum was raised against GFP isolated directly from the jellyfish, Aequorea victoria, and has been used for detection of native GFP, GFP variants, and most GFP fusion proteins (Chalfie et al. 1994; Senut et al. 2004). No staining was seen when rabbit anti-GFP antibody was applied to tissues from ears injected with wild-type D3 ESCs. The rat monoclonal antibody M2 was raised against a mouse-specific glial and neuronal cell membrane glycoprotein (Lagenaur and Schachner 1981). The M2 antibody recognizes a $45-\mathrm{kDa}$ band in Western blots and has been used widely as a marker to identify mouse neural cells in host tissues after xenogeneic transplantation (Eriksson et al. 2003; Gates et al. 1998). Anti-bcl2 reacts with bcl2 of mouse, rat, and human origin by Western blotting, immunoprecipitation, and immunohistochemistry and does not cross-react with other apoptosis-associated proteins (Thomas-Mudge et al. 2004; Weisleder et al. 2004). This antibody recognizes a single band around $29 \mathrm{kDa}$ in Western blots (manufacturer's technical information from Santa Cruz). CD45R (RA3-6B2) is a rat monoclonal IgG2a antibody raised against an extracelluar domain of the transmembrane glycoprotein CD45 and is expressed broadly among hematopoietic cells including macrophages and microglia (Bhave et al. 1998). Monoclonal anti-neurofilament 200 reacts with a single $200-\mathrm{kDa}$ band in both alkaline phosphatase dephosphorylated and untreated preparations of rat spinal cord (manufacturer's technical information from Sigma) and specifically stains nerve fibers in the inner ear (Lang et al. 2006; Wise et al. 2005). The GFAP monoclonal antibody recognizes a $50-\mathrm{kDa}$ band by immunoblotting (manufacturer's technical information from Chemicon) and has been used extensively to label astrocytes and neoplastic cells of glial lineage in the central nervous 
system (McLendon and Bigner 1994; Kasischke et al. 2006; Ward et al. 2004). Control staining for all primary antibodies included omission or substitution with similar dilutions of non-immune serum of the appropriate species. No specific staining was detected in any of the control experiments.

Secondary antibodies were biotinylated, and binding was detected with fluorescent (FITC)-conjugated avidin D (1:100; Vector, Burlingame, CA). The procedure for detection of a second antigen with double labeling was the same as for the first antigen but substituting Texas red conjugated avidin D (1:100; Vector) for visualization. Nuclei were counterstained with propidium iodide or bis-benzimide.

The sections were examined with either a Zeiss LSM5 Pascal confocal microscope (Carl Zeiss Inc., Jena, Germany) or a Zeiss Axioplan microscope equipped with a 100-W mercury light source. The captured images were processed using Image Pro Plus software (Media Cybernetics, MD), Zeiss LSM Image Browser Version 3,2,0,70 (Carl Zeiss Inc.) and Adobe Photoshop CS.

\section{Quantification of surviving ESCs and data analysis}

Five to six sections approximately $50 \mu \mathrm{m}$ apart from each other from the mid-modiolar region were used for cell counts. The observed sections included all three cochlear turns and five vestibular organs. The surviving ESCs were identified by direct fluorescent microscopy for GFP or labeling with M2 antibody in combination with the nuclear marker bis-benzimide. All data are reported as mean \pm SEM. Statistical comparisons of the number of surviving ESCs in EPI model compared to in the LPI model as well as the percentage of GFAP-positive ESCs in $\mathrm{RC}$ versus the perilymphatic space were obtained using the Student's $t$ test (SPSS, Chicago, IL). A value of $p<0.05$ was considered statistically significant.

\section{RESULTS}

The postauricular approach allows a clear view of the RW membrane and underlying structures including the basilar membrane, the basal bony osseous spiral lamina (OSL), the bony wall of RC, and part of the central modiolus (Fig. 1A). The bony wall of RC is located between the OSL and the central modiolus. The RC injection was made by inserting a glass micropipette through the RW membrane into the cavity of RC (Fig. 1B). This surgical approach limits the injections to sites within 250 to $350 \mu \mathrm{m}$ from the basal end of the cochlear spiral. Thus, the injection sites are at locations that are tuned to about $30 \mathrm{kHz}$ (Muller 1996). Most sites penetrated by the micropipette were clearly visible in H\&E-stained sections as small bony defects or repaired areas in the bony wall on the side of scala tympani.
Our previous studies have shown that application of ouabain to the RW niche of the gerbil inner ear results in degeneration of most SGNs without cell losses within the organ of Corti and cochlear lateral wall (Schmiedt et al. 2002; Lang et al. 2005). In this model, a series of apoptotic events, including a redistribution of cytochrome $\mathrm{c}$ and poly (ADP-ribose) polymerase and activation of caspase 3 , occurs in most ganglion cells within 2 days (Lang et al. 2005). Most spiral ganglion cells along with their peripheral and central processes were absent 1 week after ouabain exposure (Schmiedt et al. 2002). There are only a few surviving SGNs in RC in the gerbil 1 month after ouabain exposure (Fig. 2A, B).

ESC survival is greater in the early post-injury than in the late post-injury environment

To examine the effects of the host microenvironment on survivability of ESCs, wild-type D3 cells, D3 cells expressing GFP, and D3 cells over-expressing bcl2 were transplanted into either EPI ears, LPI ears, or normal ears (Tables 1, 2 and 3). The D3 cell line (wild-type ESCs) is an ESC line derived from the mouse blastocyst (Doetschman et al. 1985). The modification of D3 ESCs to express GFP provides a highly specific means to identify ESCs and has little effect on the survivability of these cells (Adams et al. 2003). Transplanted wild-type D3 cells and D3 cells overexpressing bcl2 can be identified by their specific morphological characteristics and positive staining with an antibody against M2, a mouse neural membrane specific protein (Eriksson et al. 2003). Table 1 is a list of the surviving ESC count data in gerbils 34 weeks after transplantation in EPI and LPI models. As described in the methods, cell leakage into the perilymphatic space (PLS) occurred near the RC injection sites. As such, for each RC injection experiment, cells were counted in both RC cavity and the PLS region (see Table 1 ).

Table 2 is a summary of the number of gerbils with robust ESC survival in EPI and LPI models. Ears were considered positive for robust ESC survival only if a mean of ten or more viable appearing ESCs were identified per section as listed in Table 1. Surviving ESCs were found in $87 \%(20 / 23)$ of EPI ears. In contrast, ESC survival was poor in LPI ears, with only about $20 \%$ $(3 / 15)$ of transplanted ears being positive. Table 3 provides a statistical comparison of surviving ESCs between the EPI and LPI models in gerbils 3-4 weeks after transplantation (the same gerbils shown in Table 1). The average number of surviving ESCs per section $(84 \pm 22.7)$ in the EPI model was about eight times that of the LPI models $(10.3 \pm 7.3)$ when the RC injection approach was used. With delivery into the PLS, the surviving ESCs in the EPI models was about 


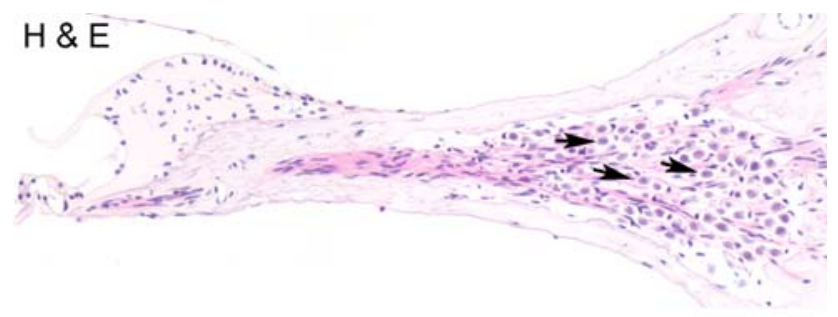

A
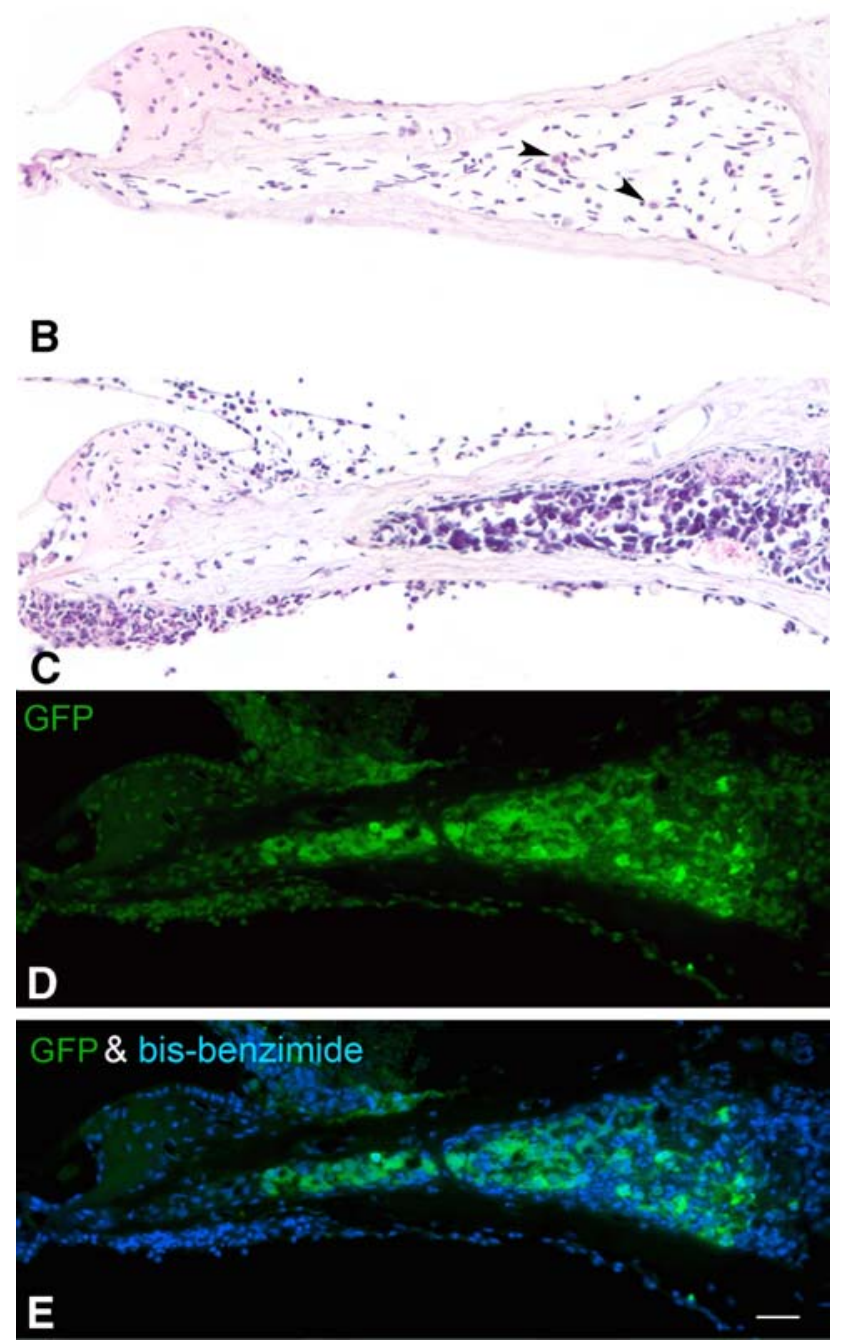

FIG. 2. Survival of transplanted ESCs in RC of ouabain-exposed cochleas. A An H\&E-stained radial section through the basal turn of the gerbil cochlea shows the normal profiles of SGNs (arrows) within RC. B Only a few neurons (arrowheads) remain in RC in a ouabainexposed cochlea 1 month after recovery. C A large number of ESCs survive in RC of an "early post-injury" (see text) cochlea 3 weeks after transplantation. ESCs are easily identified by their irregular shape and large, dark blue staining nuclei. D, E Immunostaining for GFP (green) in a section adjacent to the one shown in C identifies the grafted cells as ESCs. Nuclei were counterstained with bis-benzimide (blue). Scale bar $=50 \mu \mathrm{m}$.

three times that in the LPI models. The differences in the mean number of surviving ESCs between the EPI and LPI models are significant with either delivery approach $(p<0.05)$.
We used a modified D3 cell line that over-expressed bcl2 in nearly half the experiments with both EPI and LPI models (Tables 1 and 2). Bcl2 plays a critical role in protecting cells from insult-induced apoptosis. Previous studies have reported that over-expression of bcl2 in mice has been shown to protect a wide variety of cell types from apoptosis (Reed 1996; Zanjani et al. 1996; Simonian et al. 1997). When transplanting with ESCs over-expressing bcl2, the surviving transplanted cells were observed in all 11 animals in the EPI model, whereas only in two of nine animals in the LPI model. Similarly, transplantation of wild-type D3 cells and EGFP D3 cells resulted in surviving ESCs in 9 of 12 transplanted animals in the EPI model, but only in one of six animals in the LPI model. Our data regarding the effects of bcl2 on the survival of the implanted ESCs is limited; however, it is clear that (1) protecting ESCs from cell death by over-expressing bcl2 does not enhance survival in the LPI cochlear environment and (2) the EPI cochlear environment plays a key role in promoting the survival of transplanted ESCs regardless of bcl2 expression.

Injection of ESCs into RC in the EPI period resulted in a large number of engrafted cells within RC (Fig. 2C). These cells were identified by positive staining with ESC-specific markers (GFP or M2) or by morphological characteristics peculiar to transplanted cells, e.g., nuclei with the high nuclear to cytoplasmic ratio in the H\&E-stained sections (Fig. 2C-E). Both wild-type and $\mathrm{GFP}^{+}$ESCs survived within RC for as long as 3 weeks after transplantation into EPI ears. In EPI ears, surviving ESCs were found within RC at distances ranging from 200 to $2,000 \mu \mathrm{m}$ away from the injection site. No ESCs were detected within RC of the upper middle and apical turns. In contrast, no viable ESCs were observed anywhere within RC 3 weeks after transplanting ESCs into the LPI ears.

Endogenous $\mathrm{GFP}^{-}$cells that appeared to be derived from the host were frequently observed either singly or in clusters in RC and the scala tympani (Fig. 2C-E). Double staining with an antibody to CD45R, a commonly used marker for all types of leucocytes, indicated that only a small percentage of these $\mathrm{GFP}^{-}$cells were of hematopoietic origin (data not shown). Other possible sources of $\mathrm{GFP}^{-}$cells include residual activated glial cells, activated endothelial cells, fibroblasts, and other unknown cell types in the inner ear.

ESCs transplanted directly into perilymph of ouabain-exposed ears were found in many locations including the scala vestibuli (Fig. 3A-C, F, G) and scala tympani (data not shown) of all three cochlear turns as well as the perilymphatic spaces of the vestibular system (Figs. 3D and 8). In most cases, ESCs were delivered into the perilymphatic space by direct injection into the scala tympani through the RW membrane. However, in a few cases, ESCs were intro- 
TABLE 2

\begin{tabular}{lcccc}
\hline \multicolumn{4}{c}{ TABLE 2 } \\
\cline { 2 - 3 } & Number of gerbils with robust ESC survival 3-4 weeks after transplantation & D3/bcl2 & \\
\hline EPI & $D 3$ & $D 3 / E G F P$ & $11 / 11$ & $20 / 23$ \\
LPI & $4 / 5$ & $5 / 7$ & $2 / 9$ & $3 / 15$ \\
\hline
\end{tabular}

Cell survival was considered robust only in animal with a mean of ten or more ESCs/section.

Data are present as number of animals with robust ESCs survival/number of animals in the experimental group.

duced directly into the scala vestibuli via the micropipette after it passed through the bony spiral lamina. The defects resulting from the micropipette can be seen in H\&E-stained radial sections of the bony spiral lamina (Figs. 3B and 6C).

ESCs surviving within the perilymphatic spaces either formed an attached cell mass (Figs. 3A, B, F, G, and $6 \mathrm{~A}, \mathrm{D}-\mathrm{F}$ ) or were scattered in the perilymph as small clusters or individual cells (Fig. 3C, D). Importantly, ESC masses were present only in the EPI transplants and were never seen in the LPI condition. Most ESC masses were found near the bony wall of the scala vestibuli adjacent to the suprastrial area (Fig. 3A), within the suprastrial area (Fig. 3F, G), outside RC on the scala vestibuli side (Figs. 3B and 6C, E), and along membranes surrounding the utricle and vestibular duct (Figs. 6F and 9A).

The introduction of ESCs directly into the endolymphatic space through the RW and basilar membranes was far less successful with only a few ESCs seen in the scala media of one ear (Fig. 4). Most of these cells failed to survive as indicated by the apoptotic nuclei and cell debris in an EPI ear 11 days after ESCs were injected into endolymph (Fig. 4B, D). No ESCs were found in two other EPI cochleas 3 weeks after transplantation. Endolymphatic transplantation through the RW is a traumatic procedure owing to direct damage to the basilar membrane. Physiological measurements showed that this approach significantly reduced EP values and DPOAEs (Fig. 5A), whereas transplantation into perilymph had little effect on lateral wall and outer hair cell function (Fig. 5B).
Formation of transplanted ESC masses is associated with vascular remodeling

It is well known that angiogenesis is associated with neurogenesis in the subventricular zone and subgranular zone of the adult mammalian brain (Leventhal et al. 1999; Alvarez-Buylla and Lim 2004; Wurmser et al. 2004), but a direct link between the survival and differentiation of transplanted stem cells with the remodeling of blood vessels in the host microenvironment of injured tissues has not been reported. The vascular remodeling combined with formation of transplanted ESC masses within RC and the perilymphatic space was seen in several EPI ears, but not in LPI and normal ears (Table 1, Figs. 3, 6, 7, and 9). Histological analysis revealed a remodeling of the microvasculature within or very near the surviving ESC masses (Fig. 6). The endothelial cells in those blood vessels are easily identified by their morphological characteristics [Fig. 6A ( 1 and 2), C-E, 3, 4]. Clusters of small vessels were formed in the supralimbal region on the scala vestibuli side (Fig. 6C-F) and underneath the utricle (Fig. 6G). Vascular tube-like structures also were found within the suprastrial area in the lateral wall, adjacent to a large number of surviving ESCs in an EPI ear (data not shown). Our data suggest that there is a causal link between larger numbers of surviving grafted ESCs and neovascularization within the host microenvironment of EPI ears. Enlarged microvasculature areas were seen in the RC of EPI ears (Fig. 6A), but never in the RC of LPI and normal ears where no viable ESC masses were found. The absence

\section{TABLE 3}

\begin{tabular}{|c|c|c|c|}
\hline \multicolumn{4}{|c|}{ TABLE 3} \\
\hline \multicolumn{4}{|c|}{ Statistical comparison of surviving ESCs between EPI and LPI models } \\
\hline & \multicolumn{2}{|c|}{ Mean number ( \pm SEM) of surviving ESCS } & \multirow[b]{2}{*}{$P$ value for $E P I$ vs. $L P I$} \\
\hline Injection site (s) & EPI & $L P I$ & \\
\hline RC, PLS & $84 \pm 22.7(n=12)$ & $10.3 \pm 7.3(n=7)$ & $<0.01$ \\
\hline PLS & $29.5 \pm 9.5(n=11)$ & $7.6 \pm 4.5(n=8)$ & $<0.05$ \\
\hline
\end{tabular}

Data is from the same animals listed in Table 1. 


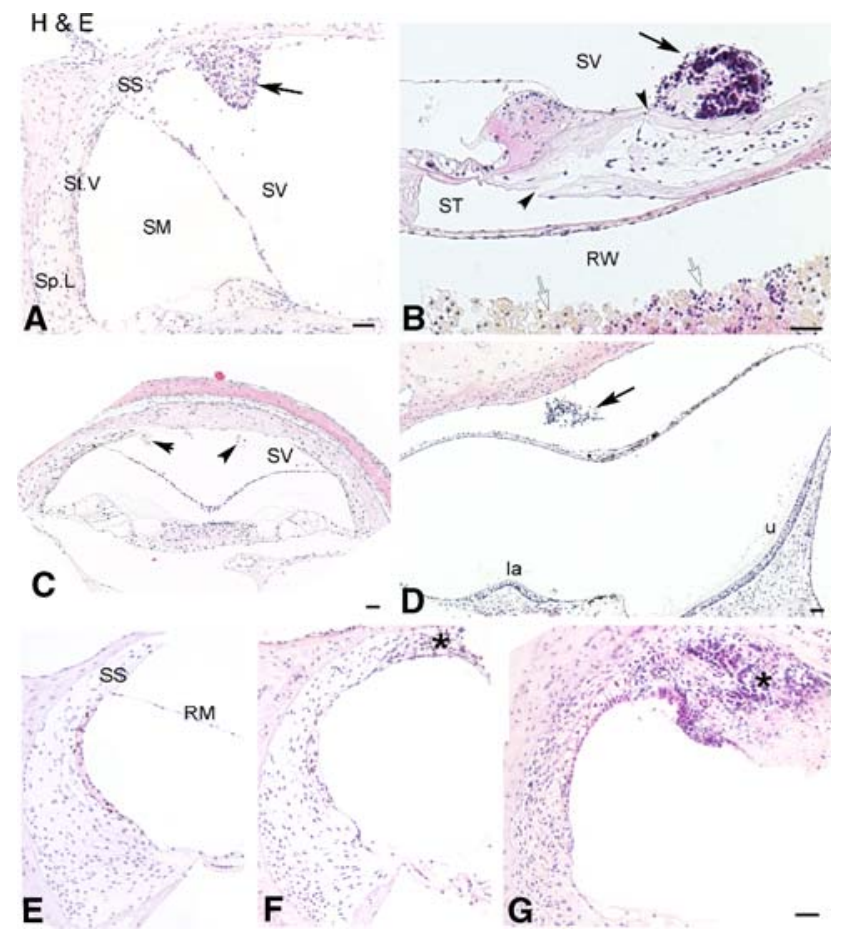

FIG. 3. Transplanted ESCs survived at several other locations in ouabain-exposed cochleas. All sections except the one in $\mathbf{E}$ were obtained from early post-injury cochleas 3-4 weeks after ESC transplantation. A A radial section through the basal organ of Corti shows an ESC mass (arrow) in the perilymphatic space of the scala vestibuli (SV) adjacent to the suprastrial (SS) area. B A mass of grafted ESCs (arrow) survived in the perilymphatic space above RC within the SV. Bony defects (arrowheads) caused by the injection pipette are evident on both the SV and scala tympani (ST) sides. There was a large amount of cell debris with some surviving ESCs (white arrows) outside the RW membrane. C ESCs were seen within the SV in the apical turn. D ESCs (arrow) were present within the perilymphatic space outside the vestibular duct. $\mathbf{E}$ Radial section through the basal turn showing the lateral wall of a normal gerbil cochlea. F, G Surviving ESCs (asterisk) are present between Reissner's membrane $(R M)$ and the SS region in the basal turn. SM scala media, St.V stria vascularis, la lateral ampulla, $u$ utricle. Scale bar $=50 \mu \mathrm{m}$.

of new or enlarged microvasculature in the LPI and normal ears suggests that the physical trauma of the injection is not able to induce neovascularization on its own.

\section{ESCs in RC differentiate toward neuronal and glial phenotypes}

A large number of surviving ESCs were found within RC 3 weeks after transplantation into EPI ears (Figs. 2, 7, and 8). Among the surviving ESCs, neuronal- and glia-like cells were identified by immunostaining with markers for mature sensory neuron and glia including neurofilament (NF) 200 and GFAP (Figs. 7 and 8).

The monoclonal NF 200 antibody labels both type I and type II neurons and their processes in mouse cochlea (Mou et al. 1998; Adamson et al. 2002; Lang

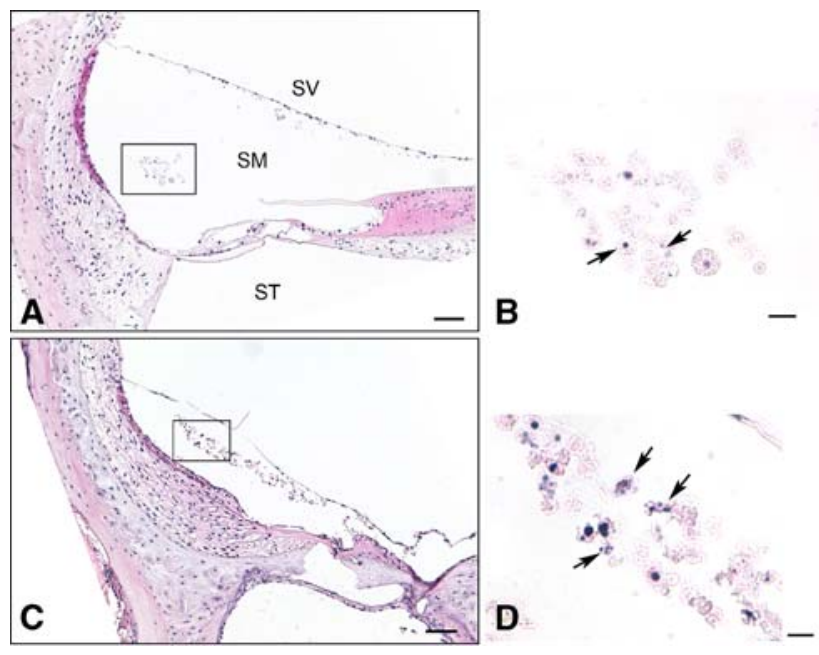

FIG. 4. ESCs survived poorly within scala media $(S M)$ after endolymphatic transplantation. A Radial section through upper basal turn of an early post-injury cochlea 11 days after ESCs were injected into endolymph. B Higher magnification view of the boxed area in $\mathbf{A}$ indicates that most ESCs within the scala media were dead or dying (arrows). C Another radial section through the organ of Corti in the hook 3 weeks after ESCs were injected into the endolymph. D: Higher magnification view of boxed area in C indicates that most ESCs within the scala media were undergoing apoptosis (arrows). Scale bar $($ for $\mathbf{A}$ and $\mathbf{C})=50 \mu \mathrm{m}$. Scale bar (for $\mathbf{B}$ and $\mathbf{D})=10 \mu \mathrm{m}$.
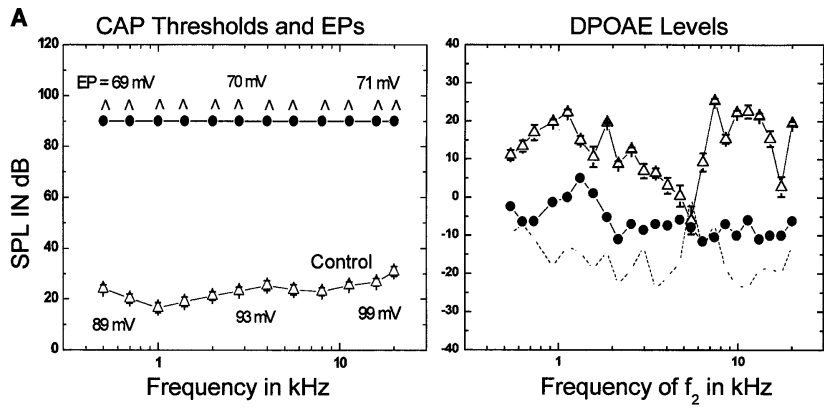

B

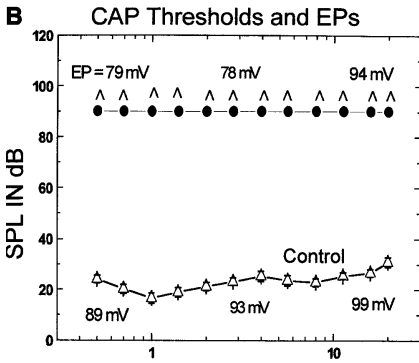

Frequency in $\mathrm{kHz}$

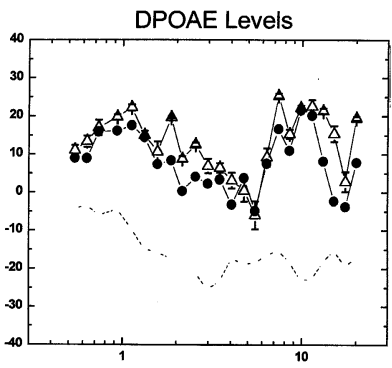

Frequency of $\mathrm{f}_{2}$ in $\mathrm{kHz}$
FIG. 5. EP values and DPOAEs were reduced after introducing ESCs into the scala media. A The same animal shown in Fig. 4a. Left panel shows that CAP responses were absent across all frequencies in the treated ear. EP values were reduced about $20-30 \mathrm{mV}$ at turn one, turn two, and turn three compared to the mean EPs from a group of control gerbils $(n=12)$. Right panel demonstrates that DPOAEs were reduced across all frequencies. Dotted line indicates the noise floor of the system. B An early post-injury cochlea 3 weeks after ESCs were injected into the perilymphatic space. Left panel demonstrates that CAP responses were absent across all frequencies in the treated ear, whereas EP values were relatively normal. Right panel showed that DPOAEs remained similar to control levels in this ear. 


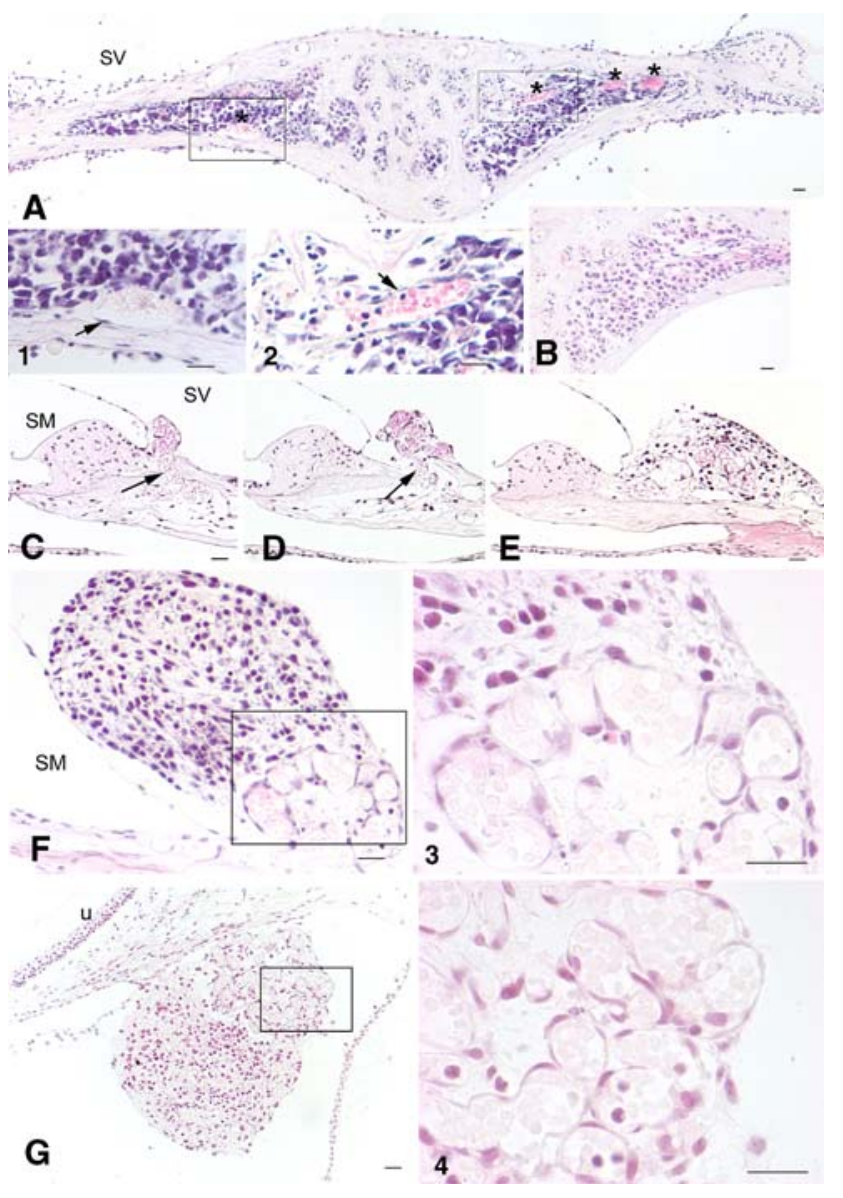

FIG. 6. Remodeling of blood vessels in early post-injury cochleas. A H\&E-stained section through RC taken 3 weeks after ESCs were introduced into RC. Increased blood vessel areas (asterisks) are evident within RC. 1, 2 Higher magnification views of the boxed areas in A showed the morphological characteristics of endothelial cells (arrows) and red blood cells. B Radial section through RC taken from a normal gerbil ear. $\mathbf{C}-\mathbf{F}$ Sections were taken from another ouabainexposed cochlea 3 weeks after transplantation. Microvessels (arrows) were found arising from RC across the broken bone and forming a cluster underneath an ESC mass in the supralimbal region. $\mathbf{C}-\mathbf{E}$ are about $20 \mu \mathrm{m}$ apart from each other. $\mathbf{F}$ is about $40 \mu \mathrm{m}$ distance from $\mathbf{E}$. 3 Higher magnification of the boxed area in F. G The section was taken from an ouabain-exposed cochlea 3 weeks after transplantation. Association of an ESC mass and a cluster of microvasculature was seen underneath of utricle. 4 Higher magnification of the boxed area in G. Scale bars $=30 \mu \mathrm{m}$.

et al. 2006; Wise et al. 2005). Dual immunostaining for GFP and NF 200 revealed several ESCs within RC that had differentiated into mature neuron-like NF-200positive cells (Fig. 7). However, cell counts in three EPI ears showed that only $4.5 \%$ of the surviving ESCs within RC stained positively for NF 200.

GFAP is the major protein constituent of glial intermediate filaments in astrocytes as well as neoplastic cells of glial lineage in the central nervous system (McLendon and Bigner 1994). GFAP is also expressed in some Schwann cells of the peripheral nervous system including Schwann cells of the sensory epithelia in the

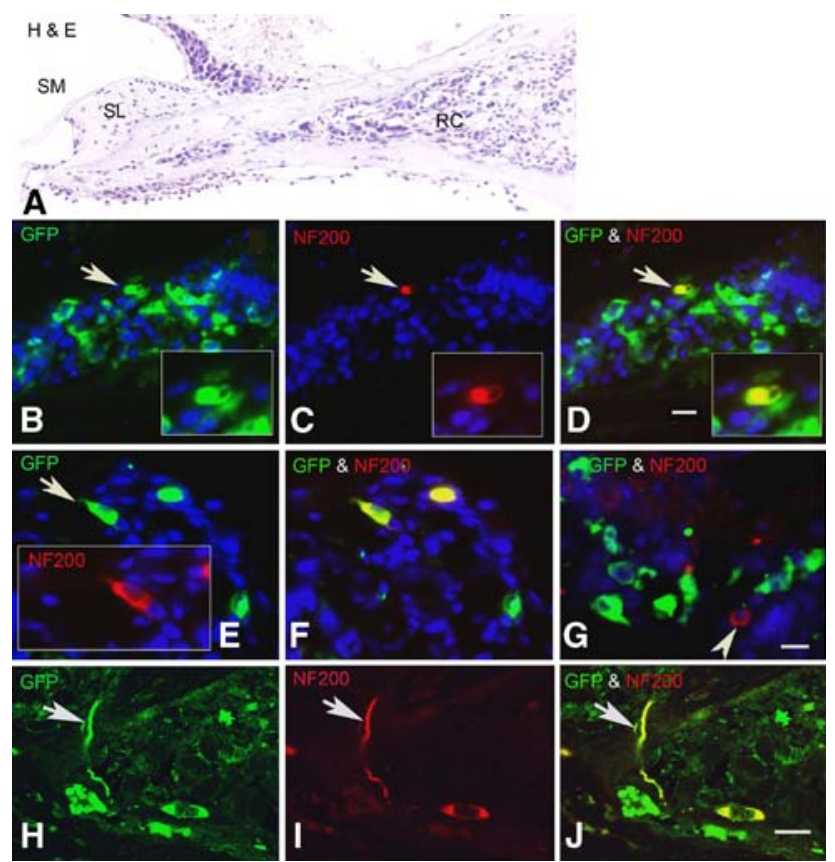

FIG. 7. Neuronal differentiation of transplanted ESCs in RC of early post-injury cochleas. All sections were obtained from two cochleas 3 weeks after transplantation with GFP-expressing ESCs. Dual immunostaining for GFP (green) and NF 200 (red) antibodies was used to identify ESCs differentiating towards a mature neuronal phenotype. A Radial section stained with H\&E shows the profile of the RC transplanted with ESCs. B-D Double staining with GFP and NF 200 antibodies shows an ESC (arrow) that has differentiated into a NF-200-positive neuron-like cell (yellow). The section is about $20 \mu \mathrm{m}$ apical to the one shown in A. E, F Section from another transplanted ear showing two NF-200-positive cells differentiated from ESCs. G A native neuron (arrowhead) remaining in RC is not GFP-positive. $\mathbf{H}-\mathbf{J}$ Confocal images of a radial section stained for GFP and NF 200 antibodies show a neuron-like cell with its process (arrow) differentiated from an ESC. The section was taken from the ear shown in sections $\mathbf{E}$ and F. SM scala media, $S L$ spiral limbus. Scale bar $=15 \mu \mathrm{m}$.

postnatal murine inner ear (Rio et al. 2002). Cell counts in four EPI ears showed that approximately $20 \%$ of the surviving ESCs were labeled for GFAP (Fig. 10). The M2 antibody has been used to identify mouse donor cells as well as glial and neuronal cells (Lagenaur and Schachner 1981). Dual immunostaining for GFAP and M2 identified a subpopulation of ESCs that had differentiated into glia-like cells within RC (Fig. 8). A subgroup of $\mathrm{M}^{+}$cells that did not label for GFAP could possibly be attributed to ESC cells differentiating toward a neuronal phenotype (Corrales et al. 2006).

Most ESCs in perilymph differentiate into glia-like cells

A large number of transplanted ESCs survived within perilymph of the scalae vestibuli and tympani as well as the perilymphatic compartments of the vestibular system (Figs. 3, 6, and 9). This finding is in agreement with previous observations that transplanted cells are 


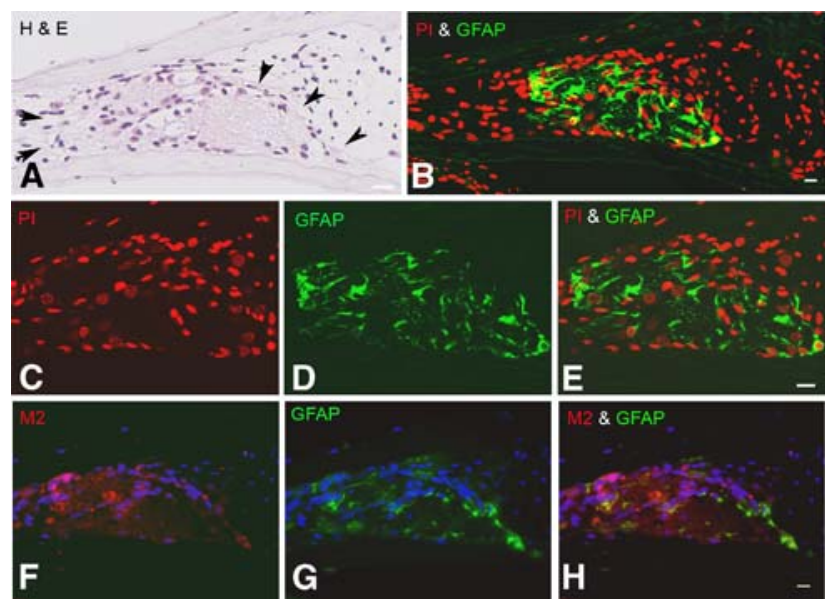

FIG. 8. Glia-like cell differentiation of ESCs in RC of early postinjury cochleas. All sections were obtained from a cochlea 3 weeks after transplantation with wild type ESCs. Dual immunostaining for M2 (red) and GFAP (green) antibodies was used to identify ESCs differentiating towards a glial phenotype. M2 is a mouse-specific antigen and can be used to identify the transplanted mouse ESCs in gerbil inner ears. A A radial section through the spiral ganglion stained with H\&E shows the profile of RC transplanted with ESCs (outlined by arrowheads). B-E Confocal images of a section adjacent to the one in A showing the morphological characteristics of transplanted glia-like cells within the RC. Note: there are no GFAPpositive cells outside the areas of the transplanted ESCs. In addition, there were also no GFAP-positive cells in the RC 3 weeks or longer after ouabain exposure (data not shown). Nuclei were counterstained with PI (red). F-H This section is about $10 \mu \mathrm{m}$ apical to the one shown in A. Dual staining with M2 and GFAP antibodies indicated that some ESCs have differentiated into glia-like cells. Nuclei were counterstained with bis-benzimide (b/ue). Scale bar $=20 \mu \mathrm{m}$.

able to survive in the scala vestibuli and scala tympani in guinea pigs, mice, and rats (Olivius et al. 2003; Hu et al. 2004, 2005; Kojima et al. 2004; Tamura et al. 2004; Yuge et al. 2004; Sekiya et al. 2006; Coleman et al. 2006). However, the differentiation potential of cells introduced into perilymphatic spaces remains unclear. The results here showed that more than $50 \%$ of the viable ESCs within the perilymphatic spaces differentiated into glia-like cells (Figs. 8, 9, and 10). In contrast, less than $20 \%$ of ESCs transplanted within $\mathrm{RC}$ differentiated into glia-like cells. Interestingly, no NF-200-positive ESCs were detected within the perilymphatic space (data not shown).

\section{DISCUSSION}

Ouabain is a cardiac glycoside that can specifically bind to $\mathrm{Na}^{+}, \mathrm{K}^{+}$-ATPase and block its activity. Our earlier work documented that introduction of ouabain into the RW niche of the gerbil cochlea resulted in a complete loss of the auditory nerve CAP response with normal function of the outer hair cells and cochlear lateral wall (Schmiedt et al. 2002; Lang et al. 2005).

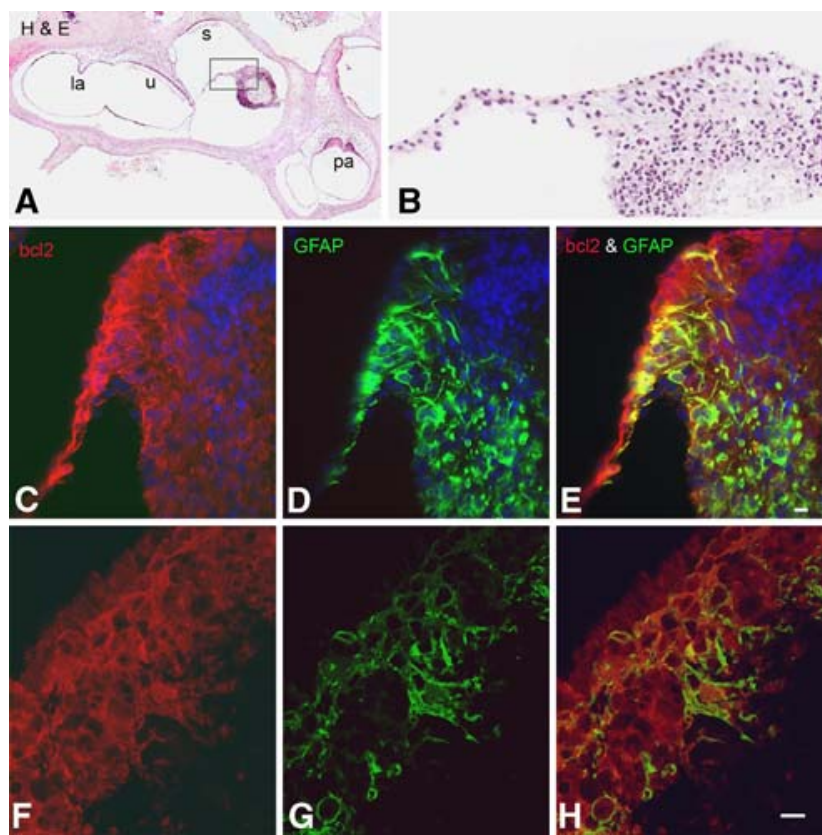

FIG. 9. Glia-like cell differentiation of ESCs in the perilymphatic space. All sections were obtained 3 weeks after transplantation with bcl2-expressing ESCs. Dual immunostaining for bcl2 (red) and GFAP (green) was used to identify ESCs differentiating towards a glial phenotype. A H\&E-stained section through most vestibular organs shows an ESC mass surviving in the perilymphatic space outside of the vestibular duct. B Enlarged image of the boxed area in A. C-E Dual staining of a section about $15 \mu \mathrm{m}$ from that shown in $\mathrm{A}$ indicated that many ESCs differentiated into glia-like cells. Note: there is a core of dying cells not expressing bcl2 located in the upper right corner of the ESC mass. Nuclei were counterstained with bisbenzimide (b/ue). F-H The morphological characteristics of the giallike cells are shown in confocal images of a section adjacent to the one in $\mathbf{C}-\mathbf{E}$. Scale bar $=15 \mu \mathrm{m}$.

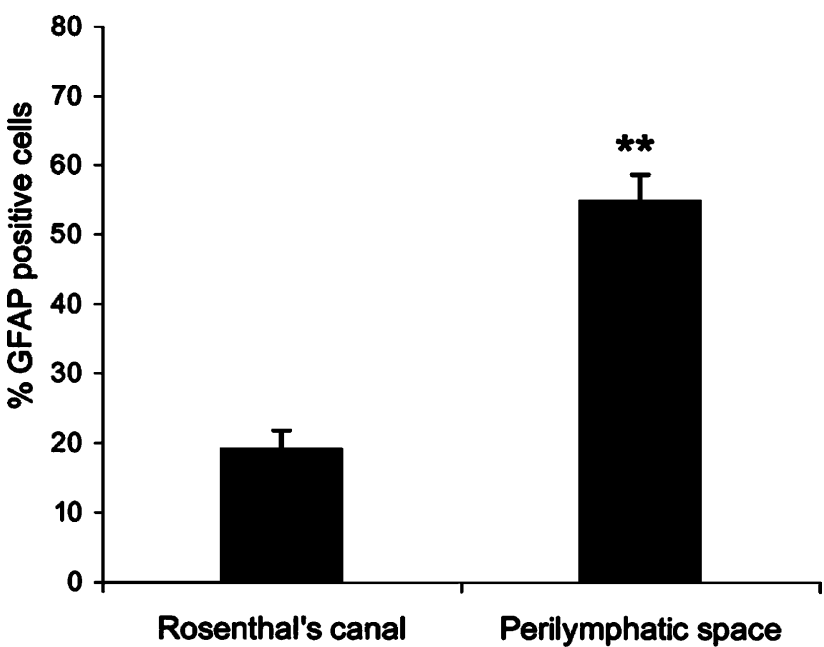

FIG. 10. The percentage of GFAP-positive ESCs in RC and perilymphatic space. The bar graph displays the results of the quantitative analysis (mean \pm SEM, $n=3$ and 8 for RC and perilymphatic space, respectively). About $55 \%$ of the ESCs transplanted into the perilymphatic space differentiated into glia-like cells. This percentage is significantly higher than that found in RC where about $19 \%$ of ESCs differentiated into glia-like cells ( $t$ test, $p>0.001$. 
The ouabain-induced SGN degeneration model provides a precise time-window for investigating the effects of the injury and subsequent alterations in the microenvironment on the survival and differentiation of engrafted ESCs. In this study, gerbils allowed to recover for 1-3 days after ouabain exposure before ESC transplantation were considered to be the "early postinjury" model, as a series of apoptotic events occurs in most ganglion neurons during this period (Lang et al. 2005). One week after ouabain exposure, most ganglion neurons together with their processes have disappeared. This pathological condition remains stable and defines the microenvironment of the "late post-injury" condition (Schmiedt et al. 2002).

Transplanted ESC survival is greater in the early than the late post-injury ears

The main finding of this study is that the transplanted ESCs survive significantly better in the EPI ears than in the LPI ears. This result suggests that the status of the microenvironment of the host inner ear is a critical factor for the viability and differentiation of transplanted ESCs. This result is also supported by recent transplantation studies in models of central nervous system injury. Keirstead et al. (2005) transplanted human ESC-derived oligodendrocyte progenitor cells (OPCs) into an animal model of spinal cord injury with demyelination. The results revealed significantly enhanced remyelination and substantial functional recovery in animals transplanted with OPCs 7 days after injury, but not in animals transplanted with OPCs 10 months after injury. Neural stem cells have been implanted directly into the infarcted regions of a hypoxic-ischemic injury in a mouse model at various time points after injury (In Park et al. 2006). When neural stem cells were implanted 3-7 days after injury, robust engraftment of neural stem cells was seen throughout the infarcted site. However, when implanted 5 weeks following injury, few engrafted cells were seen in the infarcted area. These studies, together with our results, suggest that the optimal time window of cell transplantation for grafted stem/progenitor cells survival and their potential functional benefit is limited to the EPI interval.

No data is available about how the microenvironment of injured host tissues or organs influences the survival and differentiation of transplanted stem/progenitor cells. However, numerous studies have noted that there are changes in molecular signals and related proteins, such as chemokines, neurogenic and angiogenic factors after acute injury in various animal models of brain trauma (Oyesiku et al. 1999; Miller et al. 2005; Liu et al. 2006a, b; Stowe et al. 2007). Changes in molecular signal and protein expression also have been documented in several cochlear injury models.
The up-regulation of glial cell line-derived neurotrophic factor was shown in the rat cochlea after noise exposure (Nam et al. 2000). Tumor necrosis factor alpha and vascular endothelial growth factor were upregulated in guinea pig cochlea after transcranial vibration (Zou et al. 2005). The release of growth factors or other unknown proteins into perilymph shortly after ouabain exposure may contribute to the much great survival of transplanted ESCs in the perilymphatic space in these EPI animals.

\section{Survival of transplanted ESCs in EPI ears} may be associated with neovascularization

Angiogenesis and vasculogenesis are the two major processes contributing to neovascularization in organs and tissues (Losordo and Dimmeler 2004). Neovascularization is an important event during tissue repair and regeneration after injury. Palmer et al. (2000) reported that neurogenesis in the normal adult hippocampus is intimately associated with an angiogenic process involved in recruitment of newborn endothelial cells and subsequent remodeling. Their study provides direct evidence showing adult endogenous neurogenesis taking place within an angiogenic niche. Our findings show that increased survival of engrafted stem cells in the EPI ears is also associated with the neovascularization. Although we were unable to identify the source of the neovascularization in the EPI ears with the methods used here, this should be possible by dual staining with ESC and endothelial cell specific markers.

It is possible that engrafted ESCs contribute to the neovascularization observed in the injured ear. Although the ESCs used in these studies were treated with the RA 4+/4- neural induction protocol, it is still possible that there were endothelial progenitors among the transplanted ESCs or at least that there was the capacity for endothelial differentiation. Previous in vitro studies have shown that cells from embryoid bodies generated using a similar RA 4+/4- induction protocol were composed largely of neural precursors, immature neural cells, very few differentiated neural cells, and a small percentage of non-neural cells (Meyer et al. 2004, 2005; Vadivelu et al. 2005). About 2-5\% of embryoid body cells stained positively for a specific vascular progenitor marker, Flk-1.

It is also possible that recruitment and proliferation of endogenous endothelial cells contribute to neovascularization in the injured ear. Accumulating evidence suggests that bone-marrow-derived vascular progenitor cells are able to mobilize into the peripheral circulation and contribute to neovascularization in response to various pathological conditions including cerebral ischemia (Zhang et al. 2002) and myocardial infarct (Ma et al. 2005). Unfortunately, we were unable 
to determine the precise origins of these endothelial cells in the present study. However, the coincidence of simultaneous neuronal differentiation and neovascularization in the EPI ears suggests that the injured microenvironment provides regenerative cues for both neural and vascular components. Furthermore, remodeling of blood vessels may provide a unique "neurovascular" niche for long-term survival of transplanted ESCs.

ESC survival is much greater in perilymph than in endolymph

The membranous canals within the mammalian inner ear are filled either with perilymph or endolymph. Perilymph found within the scala vestibuli and scala tympani is characterized by high sodium, low potassium, and low calcium concentrations. In contrast, endolymph in the scala media is characterized by high potassium, low sodium, and low calcium concentrations similar to those in intracellular fluids. Our results show that the survival of ESCs introduced into endolymph was very low, a not unexpected finding given the high concentration of potassium in endolymph $(\sim 160 \mathrm{mEq} / \mathrm{l})$ which makes ESC survival problematic (Okano and Iwai 1975). Although we did identify a small number of ESCs in the scala media 2 weeks after transplantation, most of these cells were dead or dying based on morphological evidence of apoptosis. Another recent study has reported that partially differentiated mouse ESCs can survive in the endolymphatic space after transplantation into scala media of the guinea pig (Hildebrand et al. 2006). A likely explanation for the ability of any cells to survive in the scala media is disruption of the normal tight-junction barrier between endolymph and perilymph by injection trauma. Sufficient mixing of endolymph and perilymph could dilute the potassium level in endolymph enough to allow cell survival. This hypothesis is supported by the finding that EP values were reduced about $20-30 \mathrm{mV}$, and distortion product otoacoustic emissions were reduced across all frequencies in gerbil cochleas 11 days after transplanting ESCs into the scala media.

A small number of transplanted ESCs were positive for mature neuron and glia markers within Rosenthal's canal

The surgical delivery of exogenous cells into the mammalian cochlea is challenging. Numerous groups have reported variable success rates of cell delivery using various deafened animal models (Hu et al. 2004, 2005; Regala et al. 2005; Okano et al. 2005; Sekiya et al. 2006; Corrales et al. 2006; Coleman et al. 2006). Among these studies, the surgical approaches used for stem cell delivery can be divided into two general categories based on the sites of injection. One approach is to introduce cells into the fluid-filled membranous channels of the inner ear, such as the scala tympani and scala media. A second approach is the of delivery cells into the various compartments housing portions of the auditory nerve, including central modiolus, vestibulocochlear nerve trunk, and the internal auditory meatus. The great advantage of the scala tympani approach is minimal trauma to the cochlea. However, the surviving cells are scattered throughout the cochlea and vestibular compartments with a relatively small number of cells migrating into RC ( $\mathrm{Hu}$ et al. 2004, 2005; Coleman et al. 2006). Approaches for introducing cells into the auditory nerve have shown better outcomes of transplanted cells. Transplanted cells are able to survive up to 3 months, migrate a considerable distance from the site of injection, and form processes that contact hair cells (Sekiya et al. 2006; Corrales et al. 2006). The disadvantage to the auditory nerve approach is the substantial disruption of the vestibulocochlear nerve by direct mechanical injury. To our knowledge, this study is the first to employ a direct injection approach to deliver ESCs into RC through the RW membrane. This surgical approach allows precise control of the number of cells delivered and minimizes surgical trauma.

A large number of transplanted ESCs were found within RC in EPI gerbil ears. Dual immunostaining for mouse stem cells with mature neuron and glia markers indicated that a small number of these ESCs differentiated into neuron- and glia-like cells. Interestingly, no NF-200-positive ESCs were found outside of RC, e.g., in the scala vestibuli or in the perilymphatic spaces of the vestibular system. This result suggests that the host microenvironment within RC provides specific cues to promote ESC differentiation towards a neuronal phenotype. A role for the host microenvironment in instructing the fate of transplanted neural stem cells has been observed in previous studies (Flax et al. 1998; Enzmann et al. 2005). When transplanted into the germinal zone of the cerebellun, human neural stem cells integrate with host tissue and differentiate into granule neurons in the emerging internal granule cell layer. However, when transplanted into the subventricular germinal zone, the same neural stem cells become astrocytes and oligodendrocytes (Flax et al. 1998). In addition, modifying the host cochlear microenvironment by co-transplanting embryonic dorsal root ganglion cells enhanced the survival and the differentiation of ESCs into neural class-III- $\beta-$ positive cells (Hu et al. 2005).

In summary, our study demonstrates that ESC survival in RC and perilymphatic spaces is much greater in the EPI microenvironment as compared to the LPI condition. The data also show that a small number of transplanted ESCs are able to differentiate into mature 
neuron- and glia-like cells that were positive for NF 200 and GFAP, respectively. Interestingly, most surviving ESCs identified in perilymph differentiated into glialike cells. Not surprisingly, the survival of transplanted ESCs is much greater in perilymph and RC than in endolymph. These results suggest that (1) the survival and differentiation of transplanted ESCs is dependent on microenvironmental cues from the host ear and (2) the optimal time window for engraftment and survival of ESCs and their potential functional benefit is limited to the early post-injury period.

\section{ACKNOWLEDGMENTS}

We are grateful to Ms. Nancy Smythe, Ms. Linda McCarson, Ms. Liya Liu, and Mr. James Nicholson for their technical and administrative assistance. We also appreciate the comments, suggestions, and guidance from Dr. Matthew C. Holley, editors, and six anonymous reviewers. Grant sponsor: National Institutes of Health; Grant number: DC07506 (H.L.); Grant number: AG14748 (R.A.S.); Grant number: DC00713 (B.A.S.); Grant number: NS45810 (L.W.); Grant number: NS45155 (L.W.); Grant number: C06 RR014516 from the Extramural Research Facilities Program of the National Center for Research Resources.

\section{REFERENCES}

Adams LD, Choi L, Xian HQ Yang A, Sauer B, Wei L, Gottlieb Di. Double lox targeting for neural cell transgenesis. Brain. Res. Mol. Brain Res. 110(2):220-233, 2003.

Adamson CL, Reid MA, Mo ZL, Bowne-English J, Davis RL. Firing features and potassium channel content of murine spiral ganglion neurons vary with cochlear location. J. Comp. Neurol. 447(4):331-350, 2002.

Alvarez-Buylla A, Lim DA. For the long run: Maintaining germinal niches in the adult brain. Neuron. 41(5):683-686, 2004.

BaIN G, GotTlieb DI. Neural cells derived by in vitro differentiation of P19 and embryonic stem cells. Perspect. Dev. Neurobiol. 5(23):175-178, 1998.

Bain G, Kitchens D, Yao M, Huettner Je, Gottlieb DI. Embryonic stem cells express neuronal properties in vitro. Dev. Biol. 168 (2):342-357, 1995.

Bhave SA, Oesterle EC, Coltrera MD. Macrophage and microglia-like cells in the avian inner ear. J. Comp. Neurol. 398(2):241-256, 1998.

Bianchi LM, Raz Y. Methods for providing therapeutic agents to treat damaged spiral ganglion neurons. Curr. Drug Targets CNS Neurol. Disord. 3(3):195-9, 2004.

Chalfie M, Tu Y, Euskirchen G, Ward WW, Prasher DC. Green fluorescent protein as a marker for gene expression. Science 263 (5148):802-805, 1994.

Chung S, Shin BS, Hedlund E, Pruszak J, Ferree A, Kang UJ, Isacson O, KIM KS. Genetic selection of sox1GFP-expressing neural precursors removes residual tumorigenic pluripotent stem cells and attenuates tumor formation after transplantation. J. Neurochem. 97(5):1467-1480, 2006.

Coleman B, Hardman J, Coco A, Epp S, de Silva M, Crook J, Shepherd R. Fate of embryonic stem cells transplanted into the deafened mammalian cochlea. Cell Transplant. 15(5):369-380, 2006.
Coleman B, de Silva MG, Shepherd RK. Concise review: The potential of stem cells for auditory neuron generation and replacement. Stem Cells 25(11):2685-2694, 2007.

Corrales Ce, Pan l, li H, Liberman mC, Heller S, Edge aS. Engraftment and differentiation of embryonic stem cell-derived neural progenitor cells in the cochlear nerve trunk: Growth of processes into the organ of Corti. J. Neurobiol. 66(13):14891500, 2006.

Dazert S, Aletsee C, Brors D, Sudhoff H, Ryan AF, Muller AM. Regeneration of inner ear cells from stem cell precursors-a future concept of hearing rehabilitation? DNA Cell Biol. 22 (9):565-70, 2003.

Doetschman TC, Eistetter H, Katz M, Schmidt W, Kemler R. The in vitro development of blastocyst-derived embryonic stem cell lines: Formation of visceral yolk sac, blood islands and myocardium. J. Embryol. Exp. Morphol. 87:27-45, 1985.

Doetzlhofer A, White PM, Johnson JE, Segil N, Groves AK. In vitro growth and differentiation of mammalian sensory hair cell progenitors: A requirement for EGF and periotic mesenchyme. Dev. Biol. 272(2):432-447, 2004.

Enzmann GU, Benton RL, Woock JP, Howard RM, Tsoulfas P, Whittemore SR. Consequences of noggin expression by neural stem, glial, and neuronal precursor cells engrafted into the injured spinal cord. Exp. Neurol. 195(2):293-304, 2005.

Eriksson C, BJoRkLund A, Wictorin K. Neuronal differentiation following transplantation of expanded mouse neurosphere cultures derived from different embryonic forebrain regions. Exp. Neurol. 84(2):615-635, 2003.

Flax JD, Aurora S, Yang C, Simonin C, Wills AM, Billinghurst Ll, Jendoubi M, Sidman RL, Wolfe JH, Kim SU, Snyder EY. Engraftable human neural stem cells respond to developmental cues, replace neurons, and express foreign genes. Nat. Biotechnol. 16 (11):1033-1039, 1998.

Gates MA, Olsson M, Bjerregaard K, Bjorklund A. Region-specific migration of embryonic glia grafted to the neonatal brain. Neuroscience 84(4):1013-1023, 1998.

Hildebrand MS, Dahl HH, Hardman J, Coleman B, Shepherd RK, DE SILVA MG. Survival of partially differentiated mouse embryonic stem cells in the scala media of the guinea pig cochlea. J. Assoc. Res. Otolaryngol. 6(4):341-354, 2006.

Hu Z, Ulfendahl M, Olivius NP. Central migration of neuronal tissue and embryonic stem cells following transplantation along the adult auditory nerve. Brain Res. 1026(1):68-73, 2004.

Hu Z, Wei D, Johansson CB, Holmstrom N, Duan M, Frisen J, ULFENDAHL M. Survival and neural differentiation of adult neural stem cells transplanted into the mature inner ear. Exp. Cell Res. 302(1):40-47, 2005.

Hu Z, Ulfendahl M. Cell replacement therapy in the inner ear. Stem Cells Dev. 15(3):449-459, 2006.

In Park K, Hack Ma, Ourednik J, Yandava B, Flax JD, Stieg Pe, Gullans S, Jensen FE, Sidman RL, Ourednik V, Snyder EY. Acute injury directs the migration, proliferation, and differentiation of solid organ stem cells: Evidence from the effect of hypoxiaischemia in the CNS on clonal "reporter" neural stem cells. Exp. Neurol. 199(1):156-178, 2006.

Ito J, Kojima K, Kawaguchi S. Survival of neural stem cells in the cochlea. Acta Otolaryngol. 121(2):140-142, 2001.

Kasischke KA, Vishwasrao HD, Fisher PJ, Zipfel WR, Webb WW. Neural activity triggers neuronal oxidative metabolism followed by astrocytic glycolysis. Science 305(5680):99-103, 2006.

Keirstead HS, Nistor G, Bernal G, Totoiu M, Cloutier F, Sharp K, STEWARD O. Human embryonic stem cell-derived oligodendrocyte progenitor cell transplants remyelinate and restore locomotion after spinal cord injury. J. Neurosci. 25(19):4694-4705, 2005.

Kojima K, Murata M, Nishio T, Kawaguchi S, Ito J. Survival of fetal rat otocyst cells grafted into the damaged inner ear. Acta Otolaryngol. Suppl. 551:53-55, 2004. 
Kondo T, Johnson SA, Yoder MC, Romand R, Hashino E. Sonic hedgehog and retinoic acid synergistically promote sensory fate specification from bone marrow-derived pluripotent stem cells. Proc. Natl. Acad. Sci. U. S. A. 102(13):4789-4794, 2005.

Lagenaur C, Schachner M. Monoclonal antibody (M2) to glial and neuronal cell surfaces. J. Supramol. Struct. Cell Biochem. 15 (4):335-346, 1981.

Lang H, Schulte BA, Schmiedt RA. Endocochlear potentials and compound action potential recovery functions in the C57BL/6J mouse. Hear Res. 172(1-2):118-126, 2002.

Lang H, Schulte BA, Schmiedt RA. Ouabain induces apoptotic cell death in type I spiral ganglion neurons, but not type II neurons. J. Assoc. Res. Otolaryngol. 6(1):63-74, 2005.

Lang H, Schulte BA, Zhou D, Smythe N, Spicer SS, Schmiedt RA. Nuclear factor kappaB deficiency is associated with auditory nerve degeneration and increased noise-induced hearing loss. J. Neurosci. 26(13):3541-3550, 2006.

Leventhal C, Rafit S, Rafit D, Shahar A, Goldman SA. Endothelial trophic support of neuronal production and recruitment from the adult mammalian subependyma. Mol. Cell Neurosci. 13 (6):450-464, 1999.

Li H, Liu H, Heller S. Pluripotent stem cells from the adult mouse inner ear. Nat. Med. 9(10):1293-1299, 2003a.

Li H, Roblin G, Liv H, Heller S. Generation of hair cells by stepwise differentiation of embryonic stem cells. Proc. Natl. Acad. Sci. U. S. A. 100(23):13495-13500, 2003b.

Li H, Corrales CE, Edge A, Heller S. Stem cells as therapy for hearing loss. Trends Mol. Med. 10(7):309-315, 2004.

Liu JJ, Shin JH, Hyrc KL, Liu S, Lei D, Holley MC, Bao J. Stem cell therapy for hearing loss: Math1 overexpression in VOT-E36 cells. Otol. Neurotol. 27(3):414-421, 2006a.

Liu XS, Zhang ZG, Zhang RL, Gregg S, Morris DC, Wang Y, CHоре M. Stroke induces gene profile changes associated with neurogenesis and angiogenesis in adult subventricular zone progenitor cells. J. Cereb. Blood Flow Metab. 27(3):564-574, $2006 \mathrm{~b}$.

Losordo DW, Dimmeler S. Therapeutic angiogenesis and vasculogenesis for ischemic disease. Part I: Angiogenic cytokines. Circulation 109(21):2487-2491, 2004.

Ma N, Stamm C, Kaminski A, Li W, Kleine HD, Muller-Hilke B, Zhang L, Ladilov Y, EgGer D, Steinhoff G. Human cord blood cells induce angiogenesis following myocardial infarction in NOD/ scid-mice. Cardiovasc. Res. 66(1):45-54, 2005, (Apr 1).

Matsui JI, Parker MA, Ryals BM, Cotanche DA. Regeneration and replacement in the vertebrate inner ear. Drug Discov. Today 10 (19):1307-1312, 2005.

McDonald JW, Liu XZ, Qu Y, Liu S, Mickey SK, Turetsky D, Gottlieb DI, Chor DW. Transplanted embryonic stem cells survive, differentiate and promote recovery in injured rat spinal cord. Nat. Med. 5(12):1410-1412, 1999.

MCLENDON RE, BIGNER DD. Immunohistochemistry of the glial fibrillary acidic protein: basic and applied considerations. Brain Pathol. 4(3):221-228, 1994.

Meyer JS, Katz ML, Maruniak JA, Kirk MD. Neural differentiation of mouse embryonic stem cells in vitro and after transplantation into eyes of mutant mice with rapid retinal degeneration. Brain Res. 1014(1-2):131-144, 2004.

MeYer JS, KATZ ML, KIRK MD. Stem cells for retinal degenerative disorders. Ann. N. Y. Acad. Sci. 1049:135-145, 2005.

Miller JT, Bartley JH, Wimborne HJ, Walker AL, Hess DC, Hill WD, CARroll JE. The neuroblast and angioblast chemotaxic factor SDF-1 (CXCL12) expression is briefly up regulated by reactive astrocytes in brain following neonatal hypoxic-ischemic injury. BMC Neurosci. 6:63, 2005, Oct 31

Mou K, Adamson CL, Davis RL. Time-dependence and cell-type specificity of synergistic neurotrophin actions on spiral ganglion neurons. J. Comp. Neurol. 402(1):129-139, 1998.
Muller M. The cochlear place-frequency map of the adult and developing Mongolian gerbil. Hear Res. 94(1-2):148-156, 1996.

NakagaWa T, Ito J. Application of cell therapy to inner ear diseases. Acta Otolaryngol. Suppl. 551:6-9, 2004.

Nam YJ, Stover T, Hartman SS, Altschuler RA. Upregulation of glial cell line- derived neurotrophic factor (GDNF) in the rat cochlea following noise. Hear Res. 146(1-2):1-6, 2000.

Nicholl AJ, Kneebone A, Davies D, Cacciabue-Rivolta DI, Rivolta MN, Coffey P, Holley MC. Differentiation of an auditory neuronal cell line suitable for cell transplantation. Eur. J. Neurosci. 22(2):343-353, 2005.

Okabe S, Forsberg-Nilsson K, Spiro AC, Segal M, McKay RD. Development of neuronal precursor cells and functional postmitotic neurons from embryonic stem cells in vitro. Mech. Dev. 59(1):89-102, 1996.

OKano Y, IwaI H. Effect of the high potassium medium on cultured cochlear epithelial cells. Arch. Otorhinolaryngol. 209(2):121$125,1975$.

Okano T, Nakagana T, Endo T, Kim TS, Kita T, Tamura T, Matsumoto M, Ohno T, Sакамото T, Iguchi F, Ito J. Engraftment of embryonic stem cell-derived neurons into the cochlear modiolus. Neuroreport 16(17):1919-1922, 2005.

Olivius P, Alexandrov L, Miller J, Ulfendahl M, Bagger-Sjoback D, Kozlova EN. Allografted fetal dorsal root ganglion neuronal survival in the guinea pig cochlea. Brain Res. 979(1-2):1-6, 2003, 25.

Oyesiku NM, Evans CO, Houston S, Darrell RS, Smith JS, Fulop ZL, Dixon CE, Stein DG. Regional changes in the expression of neurotrophic factors and their receptors following acute traumatic brain injury in the adult rat brain. Brain Res. 833(2):161172, 1999, (Jul 3).

Palmer TD, Willhoite AR, Gage FH. Vascular niche for adult hippocampal neurogenesis. J. Comp. Neurol. 425(4):479-94, 2000, (Oct 2).

Parker MA, Cotanche DA. The potential use of stem cells for cochlear repair. Audiol. Neurootol. 9(2):72-80, 2004.

Pellicer M, Giraldez F, Pumarola F, Barquinero J. Stem cells for the treatment of hearing loss. Acta Otorrinolaringol. Esp. 56(6):227232, 2005.

Rask-Andersen H, Bostrom M, Gerdin B, Kinnefors A, Nyberg G, Engstrand T, Miller JM, Lindholm D. Regeneration of human auditory nerve. In vitro/in video demonstration of neural progenitor cells in adult human and guinea pig spiral ganglion. Hear Res. 203(1-2):180-191, 2005.

REED JC. Mechanisms of Bcl-2 family protein function and dysfunction in health and disease. Behring-Inst. Mitt. 97:72-100, 1996.

Regala C, Duan M, Zou J, Salminen M, Olivius P. Xenografted fetal dorsal root ganglion, embryonic stem cell and adult neural stem cell survival following implantation into the adult vestibulocochlear nerve. Exp. Neurol. 193(2):326-333, 2005.

Rio C, Dikkes P, Liberman MC, Corfas G. Glial fibrillary acidic protein expression and promoter activity in the inner ear of developing and adult mice. J. Comp. Neurol. 442(2):156-162, 2002.

Sakamoto T, Nakagawa T, Endo T, Kim TS, Iguchi F, Naito Y, Sasai Y, ITO J. Fates of mouse embryonic stem cells transplanted into the inner ears of adult mice and embryonic chickens. Acta Otolaryngol. Suppl. 551:48-52, 2004.

Schmiedt RA, Okamura H, Lang H, Schute BA. Ouabain application to the round window of the gerbil cochlea: A model of auditory neuropathy and apoptosis. J. Assoc. Res. Otolaryngol. 03:223233, 2002.

Sekiya T, Kojima K, Matsumoto M, Kim TS, Tamura T, Ito J. Cell transplantation to the auditory nerve and cochlear duct. Exp. Neurol. 198(1):12-24, 2006.

Senut MC, Gulati-Leekha A, Goldman D. An element in the alpha1tubulin promoter is necessary for retinal expression during optic 
nerve regeneration but not after eye injury in the adult zebrafish. J. Neurosci. 24(35):7663-7673, 2004.

Simonian PL, Grillot DA, Nunez G. Bcl-2 and Bcl-XL can differentially block chemotherapy-induced cell death. Blood 90 (3):1208-1216, 1997.

Stowe AM, Plautz EJ, Eisner-Janowicz I, Frost SB, Barbay S, Zoubina EV, Dancause N, Taylor MD, Nudo RJ. VEGF protein associates to neurons in remote regions following cortical infarct. J. Cereb. Blood Flow Metab. 27(1):76-85, 2007.

Tamura T, Nakagawa T, Iguchi F, Tateya I, Endo T, Kim TS, Dong Y, Kita T, Kojima K, Naito Y, Omori K, Ito J. Transplantation of neural stem cells into the modiolus of mouse cochleae injured by cisplatin. Acta Otolaryngol. Suppl. 551:65-68, 2004.

Thomas-Mudge RJ, Okada-Ban M, Vandenbroucke F, Vincent-Salomon A, Girault JM, Thiery JP, Jounnneau J. Nuclear FGF-2 facilitates cell survival in vitro and during establishment of metastases. Oncogene 23(27):4771-4779, 2004.

Ward MM, Jobling AI, Puthussery T, Foster LE, Fletcher EL. Localization and expression of the glutamate transporter, excitatory amino acid transporter 4 , within astrocytes of the rat retina. Cell Tissue Res. 315(3):305-310, 2004.

Watters K, Li H, Corrales C, Heller S. Cell fusion in Xenotransplantation of mouse stem cell-derivatives into chicken hosts. Hosts Assoc. Res. Otolaryngol. Abstr. 27:904, 2004.

Wei L, Cui L, Snider BJ, Rivkin M, Yu SS, Lee CS, Adams LD, Gottlieb DI, Johnson EM, JR, YU SP, ChOI DW. Transplantation of embryonic stem cells overexpressing Bcl-2 promotes functional recovery after transient cerebral ischemia. Neurobiol. Dis. 19(12):183-193, 2005.
Weisleder N, TAFFet GE, CAPETANAKi Y. Bcl-2 overexpression corrects mitochondrial defects and ameliorates inherited desmin null cardiomyopathy. Proc. Natl. Acad. Sci. U. S. A. 101(3):769-774, 2004.

Wise AK, Richardson R, Hardman J, Clark G, O'Leary S. Resprouting and survival of guinea pig cochlear neurons in response to the administration of the neurotrophins brain-derived neurotrophic factor and neurotrophin-3. J. Comp. Neurol. 487(2):147-165, 2005.

Wurmser AE, Palmer TD, Gage FH. Neuroscience. Cellular interactions in the stem cell niche. Science 304(5675):1253-1255, 2004.

Yuge I, Takumi Y, Koyabu K, Hashimoto S, Takashima S, Fukuyama T, Nikaido T, Usami S. Transplanted human amniotic epithelial cells express connexin 26 and $\mathrm{Na}-\mathrm{K}$-adenosine triphosphatase in the inner ear. Transplantation 77(9):1452-1454, 2004.

Zanjani HS, Vogel MW, Delhaye-Bouchaud N, Martinou JC, Mariani $\mathrm{J}$. Increased cerebellar Purkinje cell numbers in mice overexpressing a human bcl-2 transgene. J. Comp. Neurol. 374 (3):332-341, 1996.

Zhai S, Shi L, Wang BE, Zheng G, Song W, Hu Y, Gao WQ. Isolation and culture of hair cell progenitors from postnatal rat cochleae. J. Neurobiol. 65(3):282-293, 2005.

Zhang ZG, Zhang L, Jiang Q, Chopp M. Bone marrow-derived endothelial progenitor cells participate in cerebral neovascularization after focal cerebral ischemia in the adult mouse. Circ. Res. 90(3):284-288, 2002.

Zou J, Pyyko I, Sutinen P, Toppila E. Vibration induced hearing loss in guinea pig cochlea: expression of TNF-alpha and VEGF. Hear. Res. 202(1-2):13-20, 2005. 